\title{
Strategic Alliances And New Product Development In High-Tech Ventures: The Moderating Role Of Alliance Type And Alliance Capability
}

Sang-Mi Moon, Korea Institute for Robot Industry Advancement (KIRIA), South Korea Moon-Goo Huh, Kyungpook National University, South Korea

\begin{abstract}
Strategy scholars have proposed that capacity for managing alliance can be a source of superior performance. This study focuses on the role of this capacity, and investigates how alliance management capability of entrepreneurial firms affects the relationship between a firm's allying and its performance. Because the capability is inherently unobservable, we take alliance experience and average duration of each alliance as proxy variables for measuring alliance management capability. An analysis of multiple allies of entrepreneurial ventures in Korean photovoltaic industry indicate that capacity for managing varying allies, and alliance type positively moderate the relation between alliance and its innovation outcomes.
\end{abstract}

Keywords: Alliance; Alliance Management Capability; Alliance Type; High-Tech Ventures; New Product Development

\section{INTRODUCTION}

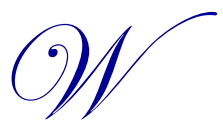

ith the frequent use of strategic alliances in various industries, it has evolved into important strategic tools. However, despite the phenomenal use of strategic alliances, extant research has found that more than half of strategic alliances do not live up to expectations, and the results of alliance failure can be drastic (Koza \& Lewin, 2000; Park \& Ungson, 2001). The investigation of the drivers of alliance effectiveness has become a critical subject (Hoang \& Rotharmel, 2005; Koka \& Prescott, 2008; Krishnan, Martin \& Noorderhaven, 2006; Lavie, Haunschild, \& Khanna, 2012).

Previous studies have shown that the outcomes of each alliance differ significantly across firms (Harbison \& Pekar, 1998). Although some firms exploit the diverse benefits from alliances, much more firms are not able to do so. Therefore, alliance researchers have increasingly focused on organizational-level factors that can resolve why some organizations are more likely to achieve alliance success than are others (Heimeriks \& Duysters, 2007; Reuer \& Ragozzino, 2006; Schilke \& Goerzen, 2010; Schreiner, Kale, \& Corsten, 2009; Vandale \& Zaheer, 2014). Strategic alliance is voluntary arrangement among independent organizations aimed at developing and commercializing new products, technologies, or services (Gulati, 1998). Across a broad range of industry, alliance has become an indispensable element of firm-level strategy (Wassmer, 2010).

Especially most entrepreneurial firms lacking resources and competences are simultaneously participated in multiple allies and are confronted with the difficult tasks of managing a whole portfolio of alliances (Bamford \& Ernst, 2002; Duysters, Heimeriks, Lokshin, Meijer \& Sabidussi, 2012; George, Zahra, Wheatley, \& Khan, 2001; Lavie, 2007; Lavie \& Miller, 2008; Parise \& Casher, 2003; Wuyts \& Dutta, 2014). Accordingly, alliances have become one of the crucial drivers for the success of entrepreneurial firms. Commensurately, recent research have suggested that firms' capabilities for managing alliances differs significantly across firms and that this can be a crucial factor in explaining competitive advantage (Ireland, Hitt, \& Vaidyanath, 2002). It is important, thus, to understand how firm- 
level and alliance-specific elements affect a company's capability to manage its allies in a business environment.Previous studies have found that a start-up's alliances can facilitate its innovation, IPO efforts, and performance (sales) (Kelley \& Rice, 2002; Leiblein \& Reuer, 2004; Stuart, Hoang \& Hybels, 1999). Some other research has also suggested that alliance increases the performance of entrepreneurial firms but excessive alliance activities may lead to diminishing returns (Deeds \& Hill, 1996). Dealing with established firms rather than entrepreneurial ventures, prior research have shown that alliance experience can increase market value (Anand \& Khanna, 2000) and enhance the development of new products (Rothaermel, 2001).

Prior work has insisted that alliance experience positively affects its outcomes. However, few studies have empirically investigated the factors determining alliance management capability, mainly because of methodological constraints. The present study argues that a firm's capability of managing alliance could be a source of superior performance only when it has tangible benefits (Godfrey \& Hill, 1995; Heimeriks \& Duysters, 2007; Schilke \& Goerzen, 2010; Vandale \& Zaheer, 2014). Among tangible benefits mentioned in this context, one is the ability of companies to manage the alliance productively, which therefore should have a positive effect on its performance. Our goal is to explore the impact of alliance-related factors on the alliance management capability of high-tech venture companies. To meet the purposes of this study, we conceptualize alliance management capability as a capacity of an enterprise to manage multiple allies effectively.

To empirically explore the construct, we first hypothesize an inverted U-shaped relation between alliance of ventures and new product development. In particular, we demonstrate that this relation also applies to different alliance types such as R\&D and marketing alliance. We follow this argument by empirically establishing that the point of decreasing returns can be a proxy for level of alliance management capacity.

This study then turns to the drivers of capacity for managing alliances. We propose that varying types of alliances require different capacity for managing each alliance. In addition, we also propose that the capacity for managing diverse alliances is cultivated through cumulated experience and time period. Put differently, the more experience of alliances and the longer its alliance history, the more likely the firm is to productively manage its alliances. We develop and test the hypotheses in the context of Korean photovoltaic industry in 2007-2011 period.

\section{THEORY AND HYPOTHESES}

\section{Alliances and the Development of New Products}

Extant research has found that alliance has positive impact on the performance of new ventures. However, it should be noted that new ventures lacks sufficient resources and management capabilities. Hence the relation between firm allies and their innovation outcomes stemmed from its allies might reveal decreasing returns beyond some point. In this regard, some studies have correlated a high level of alliance activity with negative returns in high-tech ventures (Deeds \& Hill, 1996). When it comes to increasing the diversity of their alliance portfolios, businesses encounter tradeoffs. On the one hand, the opportunities of value creation and capability development could be offered by a highly diversified alliance portfolio that provides broad range of search options and in-depth resource pools. On the other hand, increased coordination and managerial costs could be achieved by increased diversification which brings more complexity and the likelihood for more conflicts (Golden \& Zajac, 2001; Jiang, Tao, \& Santoro, 2010).

Some conjectures about the diminishing benefits exploited from diverse alliances are as follows. With an increasing types and numbers of alliances, entrepreneurs and managers are more likely to experience information overload. Such an increase can bring about transaction costs, leading to negative returns for large numbers of allies. Secondly, the more attractive alliances are more likely to formed beforehand, less attractive alliances may be entered later (Rothaermel \& Deeds, 2006). Based on the above discussions, we propose an inverted U-shape relation between the quantity of a high-tech venture's allies and its new product development performance.

Hypothesis 1: There is an inverted U-shaped relationship between the total number of a high-tech venture's alliances and its development of new products. 


\title{
Alliance Type and NPD (New Product Development)
}

Existing studies have not been successful to apply this relation to varying alliance types. Before examining the relation between the alliance type and the capacity for handling its alliances, we need to reveal whether the relationship can be held to different categories of alliances. Since start-ups are inclined to form alliances with diverse organizations, it is needed to generalize their relationships into varying types of alliances. After determining whether the relationship can be generalized, we can explore the effects of alliance type on the capacity for handling different alliances.

A firm faces diverse challenges in managing different types of alliances because each alliance is likely to make unique requirements on its capacity for handling varying alliances. Such requirements emanate from two aspects: varying types of alliance and knowledge transferred through its alliances.

Firms forging R\&D alliances generally engage in exploration, searching for new technologies and distant knowledge. In this vein, exploratory alliances involve upstream activities of the value chain, whereas exploitative alliances entail downstream activities, such as marketing and distribution. Exploration needs more engagement in alliances to fully realize the potential benefits. Therefore, high-tech ventures lacking sufficient capabilities are likely to be troublesome in dealing with $R \& D$ alliances rather than marketing alliances.

Hypothesis 2: The type of alliance moderates the relation between a high-tech venture's allies and its development of new products. That is, a firm with marketing alliances can manage more alliances than that with R\&D alliances.

\begin{abstract}
Alliance Management Capability
Strategic alliances among different organizations cause a variety of managerial and governing challenge (Rothaermel \& Deeds, 2006). Accordingly, regardless of the alliance purpose and type, many alliances do not live up to their expectations. Some research has found that performance of alliances varies considerably among firms (Sampson, 2007), implying that each organization has its own capacities and routines for managing multiple alliances (Reuer \& Ragozzino, 2006). Thus, a series of research has focused on identifying firm-level factors affecting alliance outcomes (Anand \& Khanna, 2000; Hoang \& Rothaermel, 2005; Lavie, Haunschild \& Khanna, 2012; Rothaermel \& Deeds, 2006; Zollo, Reuer \& Singh, 2002). Alliance management capability represents these streams of research.
\end{abstract}

A certain organizational capacity for managing alliances might be built over time through diverse and cumulated allies. Prior work has created some evidence that alliance experience has an effect on diverse measures of alliance outcomes (Anand \& Khanna, 2000; Sampson, 2002; Deeds \& Hill, 1996). Based upon a resource-based theory, a certain capability for managing different alliances can be a source of competitive advantage if it is heterogeneous among firms and difficult to imitate (Barney, 1991). This study pays special attention to alliance experience and history as proxy variables representing firm-specific alliance management capability.

\section{Alliance Experience and Capacity for Managing Alliance}

Organizational competencies in managing alliances are constructed over time through cumulated commitments to various alliances. The benefits of experience result from learning by doing through recurred involvements in the activity. Research has found that learning by doing effects take place not only in the manufacturing sector, but in the service industries (Argote, 2012; Oliva \& Sterman, 2001). Through repeated alliances, organizations are able to generate policies, structures, processes, routines, and tacit knowledge for managing diverse alliances. Managing alliances covers a full range of alliance management processes, which involve searching and selecting partners, structuring and governing alliances, and building and developing partnerships. High-tech ventures with substantial alliance experience are likely to be more innovative than are those with less experience. Furthermore, some research found that previous experience with the same ally contributes positively to the outcomes of following alliances with the identical partner (Zollo, Reuer, \& Singh, 2002). Taken together, this study proposes that the alliance performance relation is positively moderated by a firm's cumulative allying experience. 
A firm's alliance management capability can be defined as a capacity to deal with multiple alliances productively. An entrepreneurial firm's repeated alliances may contribute, over time, to the establishment of the alliance management capacity, which the venture could exploit to improve the outcomes of its subsequent allies (Hoang \& Rothaermel, 2005; Rothaermel \& Deeds, 2006). Although an organizational capability for alliance management tends to be built by means of repeated allies, new ventures can still accumulate alliance experience in a meaningful fashion. This indicates that a new venture can form several alliances simultaneously in the early stage of its development so as to accumulate the experience more quickly.

Therefore, a firm's accumulative experience of diverse alliances moderates the relation between alliance and its innovation outcome. Ceteris paribus, the more allying experience a firm has, the greater capability one has to manage more alliances in an effective manner. These arguments concerning the moderating role of allying experience apply equivalently to the alliance period, which means the cumulative duration of a firm's varying alliances. Therefore, we propose the following hypotheses.

Hypothesis 3: A high-tech venture's allying experience moderates the relation between the venture's alliances and its development of new products. That is, a firm with more allying experience affords to govern more alliances.

Hypothesis 4: A high-tech venture's cumulative alliance duration moderates the relation between the venture's alliances and its development of new products. That is, a firm with a longer alliance period is able to manage more alliances.

\section{METHODS}

\section{Data and the Sample}

We chose Korea's photovoltaic industry as the research setting. Photovoltaic technology has many things in common with main industries of Korea, such as semiconductor and display. Thus, it is believed that the industry has potential to develop rapidly. The industry has grown exponentially along with the strong support of the government. The industry structure has common characteristics according to the size of the companies. Big firms tend to develop vertical integration along the industry (solar) value chain, whereas small firms specialize into specific business domain across the value chain. These industry structures propel firms to make allies with other organizations to make up their market position. To generate the sample, we classified all photovoltaic firms registered in the Korea Institute of Industrial Technology's industry analysis report. We then conducted a survey which includes 225 alliances of 85 Korean photovoltaic firms for five year (2007-2011) time frame.

\section{Variables and Measures}

New Product Development (NPD)

The dependent variable is a firm's development of new products. It represents one of representative measures of firm innovation. To determine the number of new products, we included the products under development to the products on the market. This measure enables to evaluate the innovation outcomes more accurately from a venture firm's allying (Rothaereml \& Deeds, 2006).

\section{Alliance and Type of Alliance}

We calculated a firm's allying by adding up the quantity of its allies, and then classified the allies into R\&D and marketing alliance.

\section{Alliance Experience}

We summed up a venture's total alliances from its founding year and used it as a proxy for its alliance experience (Kale \& Singh, 1999; Tsang, 2002). We divided the sample into two groups by allying experience to examine the moderating effect of allying experience on the alliance-innovation relationship. This approach which splitting the 
sample into subgroups is particularly effective when the study intends to examine the effects of moderating variables on the non-linear relationship. In particular, this approach allows for the determination of any significant differences in the point of diminishing returns.

\section{Alliance Period}

We used the average duration of a firm's total alliances as a proxy for alliance history (Heimeriks \& Duysters, 2007). To examine the moderating effect on a curvilinear relation, we took the same approach above mentioned. That is, we divided the sample into two groups by their average duration of total alliances and tested the moderating effect whether alliance period affects the relation between firm alliance and innovation outputs.

\section{Control Variables}

Some control variables were included to account for alternate explanations of entrepreneurial firm's innovation performance. We controlled for firm size, age, and innovativeness. Considering the characteristics of Korean photovoltaic industry, we operationalized firm size by the number of employees, firm age by the number of years since its founding, and innovativeness by the number of patents which the venture registered or applied. In the photovoltaic industry, the number of patents can be a better proxy for innovativeness than patent citations because the latter needs much longer time frame and can be distorted toward more aged patents.

\section{RESULTS}

Table 1 reports means, standard deviations, and bivariate correlation coefficients for all variables of this study. Table 2 shows the results of GLM Poisson regression for testing H1 and H2. Model 1 is the base model and only enters the control variables. Each following model shows a significant improve over Model 1. Model 2 presents the effect of firm allying on new product development. Models 3 and 4 assess the individual effect of each type of alliance on NPD.

Table 1. Summary statistics and bivariate correlations

\begin{tabular}{|c|c|c|c|c|c|c|c|c|c|c|}
\hline & Mean & S.D & 1 & 2 & 3 & 4 & 5 & 6 & 7 & 8 \\
\hline $\begin{array}{l}\text { 1. New product } \\
\text { development }\end{array}$ & 5.96 & 4.99 & & & & & & & & \\
\hline 2. Firm size & 263.22 & 359.13 & .43 & & & & & & & \\
\hline 3. Firm age & 17.56 & 10.12 & .41 & .14 & & & & & & \\
\hline $\begin{array}{l}\text { 4. Firm } \\
\text { innovativeness }\end{array}$ & 4.88 & 13.95 & .34 & .17 & .37 & & & & & \\
\hline $\begin{array}{l}\text { 5. Marketing } \\
\text { alliance }\end{array}$ & 2.23 & 2.45 & $.13^{*}$ & .19 & .33 & .28 & & & & \\
\hline 6. R\&D alliance & 1.52 & 2.34 & $.31^{* *}$ & .21 & .19 & .23 & .07 & & & \\
\hline $\begin{array}{l}\text { 7. Alliance } \\
\text { experience }\end{array}$ & 5.41 & 4.87 & $.21^{*}$ & .55 & .41 & .17 & .13 & $.06^{*}$ & & \\
\hline 8. Alliance period & 1.4 & 4.56 & .23 & .17 & .03 & .18 & .23 & .04 & $.46^{*}$ & \\
\hline 9. Total alliance & 2.96 & 5.99 & $.49^{* * *}$ & .51 & .34 & .31 & .41 & .22 & .36 & .40 \\
\hline
\end{tabular}


Table 2. Result of GLM Poisson regression predicting new product development

\begin{tabular}{|c|c|c|c|c|c|}
\hline & Model 1 & Model 2 & Model 3 & Model 4 & Model 5 \\
\hline Intercept & $\begin{array}{l}1.22^{*} \\
(.031)\end{array}$ & $\begin{array}{l}1.30^{* *} \\
(.035)\end{array}$ & $\begin{array}{l}1.31^{* * *} \\
(.041)\end{array}$ & $\begin{array}{l}1.29^{* * *} \\
(.037)\end{array}$ & $\begin{array}{l}1.32^{* * *} \\
(.049)\end{array}$ \\
\hline Firm size & $\begin{array}{l}0.06^{* *} \\
(.022)\end{array}$ & $\begin{array}{l}0.02 \\
(.026)\end{array}$ & $\begin{array}{l}0.05^{* *} \\
(.026)\end{array}$ & $\begin{array}{l}0.05^{* *} \\
(.028)\end{array}$ & $\begin{array}{l}0.03 \\
(.031)\end{array}$ \\
\hline Firm age & $\begin{array}{l}0.12^{* * * *} \\
(.049)\end{array}$ & $\begin{array}{l}0.08^{* *} \\
(.039)\end{array}$ & $\begin{array}{l}0.11^{* * * *} \\
(.047)\end{array}$ & $\begin{array}{l}0.07^{*} \\
(.038)\end{array}$ & $\begin{array}{l}0.06^{*} \\
(.035)\end{array}$ \\
\hline $\begin{array}{l}\text { Firm } \\
\text { innovativeness }\end{array}$ & $\begin{array}{l}0.03 \\
(.032)\end{array}$ & $\begin{array}{l}0.05 \\
(.045)\end{array}$ & $\begin{array}{l}0.04 \\
(.031)\end{array}$ & $\begin{array}{l}0.01 \\
(.028)\end{array}$ & $\begin{array}{l}0.06 \\
(.051)\end{array}$ \\
\hline Total alliance & & $\begin{array}{l}0.34^{* * *} \\
(.04)\end{array}$ & & & \\
\hline$(\text { Total alliance })^{2}$ & & $\begin{array}{c}-0.05^{* *} \\
(.01)\end{array}$ & & & \\
\hline R\&D alliance & & & $\begin{array}{l}0.16^{*} \\
(.06)\end{array}$ & & $\begin{array}{l}0.17^{* *} \\
(.06)\end{array}$ \\
\hline$(\mathrm{R} \& \mathrm{D} \text { alliance })^{2}$ & & & $\begin{array}{r}-0.02^{*} \\
(.01)\end{array}$ & & $\begin{array}{r}-0.03^{*} \\
(.01)\end{array}$ \\
\hline Marketing alliance & & & & $\begin{array}{l}0.24^{* *} \\
(.03)\end{array}$ & $\begin{array}{l}0.18^{* *} \\
(.05)\end{array}$ \\
\hline $\begin{array}{l}\text { (Marketing } \\
\text { alliance) })^{2}\end{array}$ & & & & $\begin{array}{r}-0.02^{*} \\
(.01)\end{array}$ & $\begin{array}{r}-0.01^{*} \\
(.01)\end{array}$ \\
\hline Log likelihood & -204.71 & -173.62 & -192.43 & -182.07 & -169.82 \\
\hline Chi-square & $126.28^{* * *}$ & $189.02^{* * *}$ & $131.56^{* *}$ & $145.78^{* *}$ & $191.97^{* * *}$ \\
\hline $\begin{array}{l}\text { Improvement over } \\
\text { base }\end{array}$ & & $62.74^{* * *}$ & $5.28^{* * *}$ & $19.5^{* * *}$ & $65.69^{* * *}$ \\
\hline
\end{tabular}

Figure 1. Illustration of the moderating effect of allying type on the relation between alliance and NPD

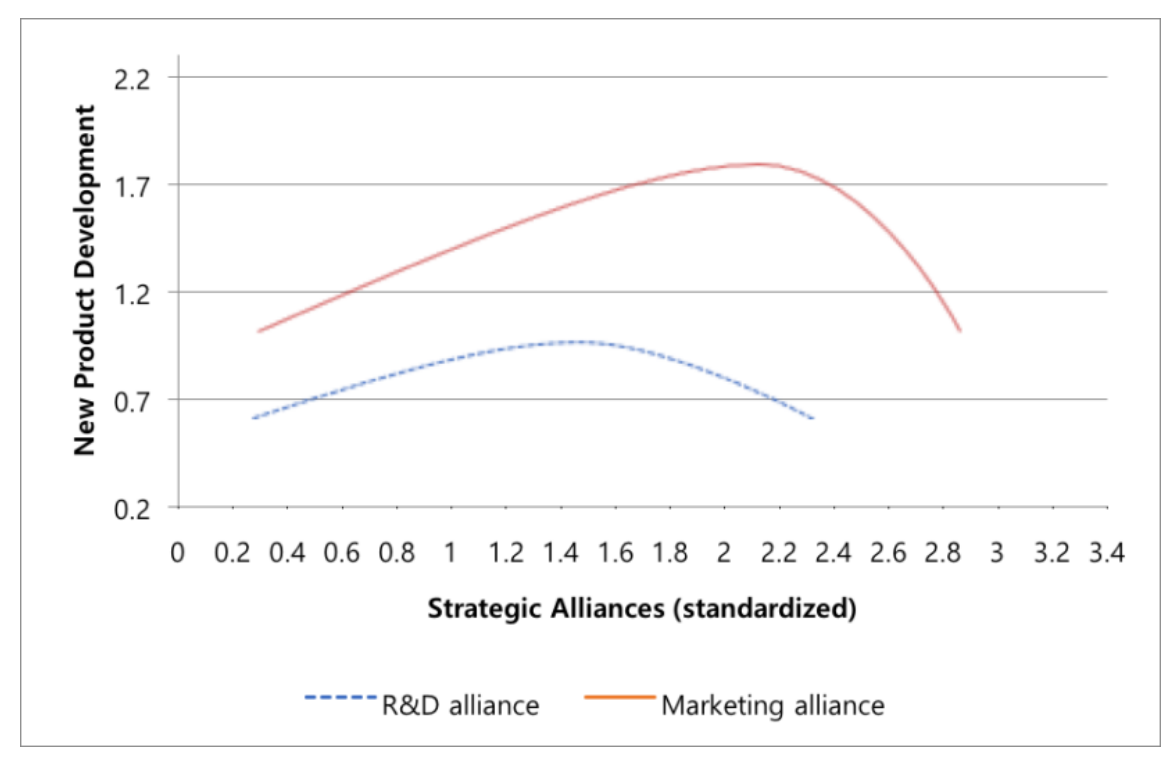

Hypothesis 1 predicts that in the context of high-tech ventures, alliance and innovation would have an inverted Ushaped relationship and this relation would hold for all types of alliances. Hypothesis 2 predicts that varying types of alliances would posit different capacity for managing alliance, with R\&D alliances requiring higher level of capacity and marketing alliances requiring smaller level. 
To test these hypotheses, we followed the methodological approach which Rothaermel \& Deeds (2006) suggested. First, we determined the inflection point of decreasing returns for each type of alliance on a venture's innovation output (NPD). Reflecting differential needs for managing alliance, we first put R\&D alliances in the point of decreasing returns, and then marketing alliances next. In order to determine each inflection point, we took the partial derivatives regarding each type of alliance (Rothaermel \& Deeds, 2006) and found an increase in the inflection point from 1.37 for $R \& D$ alliances to 2.51 for marketing alliances. This implies that alliance type moderates the relation between alliance and NPD. The results indicate that entrepreneurial firms are able to manage more marketing alliances rather than R\&D alliances, supporting Hypothesis 2. Figure 1 further confirms the above described results, which reveals that $\mathrm{R} \& \mathrm{D}$ alliance comes to its inflection point first, and followed by marketing alliance.

Table 3. Result of GLM Poisson regression predicting NPD for subgroups of low- and high-level of allying experience

\begin{tabular}{|c|c|c|c|c|}
\hline & \multicolumn{2}{|c|}{ Low level of alliance experience } & \multicolumn{2}{|c|}{ High level of alliance experience } \\
\hline & Model 6 & Model 7 & Model 8 & Model 9 \\
\hline Intercept & $\begin{array}{l}1.23^{* * *} \\
(.04)\end{array}$ & $\begin{array}{l}1.27^{* * *} \\
(.04)\end{array}$ & $\begin{array}{l}1.95^{* * *} \\
(.05)\end{array}$ & $\begin{array}{l}2.01^{* * *} \\
(.05)\end{array}$ \\
\hline Firm size & $\begin{array}{l}0.10^{* *} \\
(.03)\end{array}$ & $\begin{array}{l}0.09^{* *} \\
(.03)\end{array}$ & $\begin{array}{l}0.09^{*} \\
(.05)\end{array}$ & $\begin{array}{l}0.02 \\
(.04)\end{array}$ \\
\hline Firm age & $\begin{array}{l}0.04^{*} \\
(.04)\end{array}$ & $\begin{array}{l}0.08^{*} \\
(.04)\end{array}$ & $\begin{array}{l}0.08^{* *} \\
(.04)\end{array}$ & $\begin{array}{l}0.07^{*} \\
(.05)\end{array}$ \\
\hline Firm innovativeness & $\begin{array}{l}0.04 \\
(.02)\end{array}$ & $\begin{array}{l}0.01 \\
(.02)\end{array}$ & $\begin{array}{l}0.02 \\
(.04)\end{array}$ & $\begin{array}{l}0.08^{*} \\
(.07)\end{array}$ \\
\hline Total alliance & & $0.09^{* *}(.05)$ & & $\begin{array}{l}0.30^{* *} \\
(.08)\end{array}$ \\
\hline (Total alliance) 2 & & $-0.08^{* *}(.02)$ & & $\begin{array}{c}-0.07^{* *} \\
(.02)\end{array}$ \\
\hline Log likelihood & -160.91 & -152.13 & -165.12 & -159.32 \\
\hline Chi-square & $42.27^{* * *}$ & $62.45^{* * *}$ & $58.97^{* * *}$ & $81.35^{* * *}$ \\
\hline Improvement over base & & $20.18^{* * *}$ & & $22.38^{* * *}$ \\
\hline
\end{tabular}

Improvement over base

Figure 2. Illustration of the moderating effect of allying experience on the relation between alliance and NPD

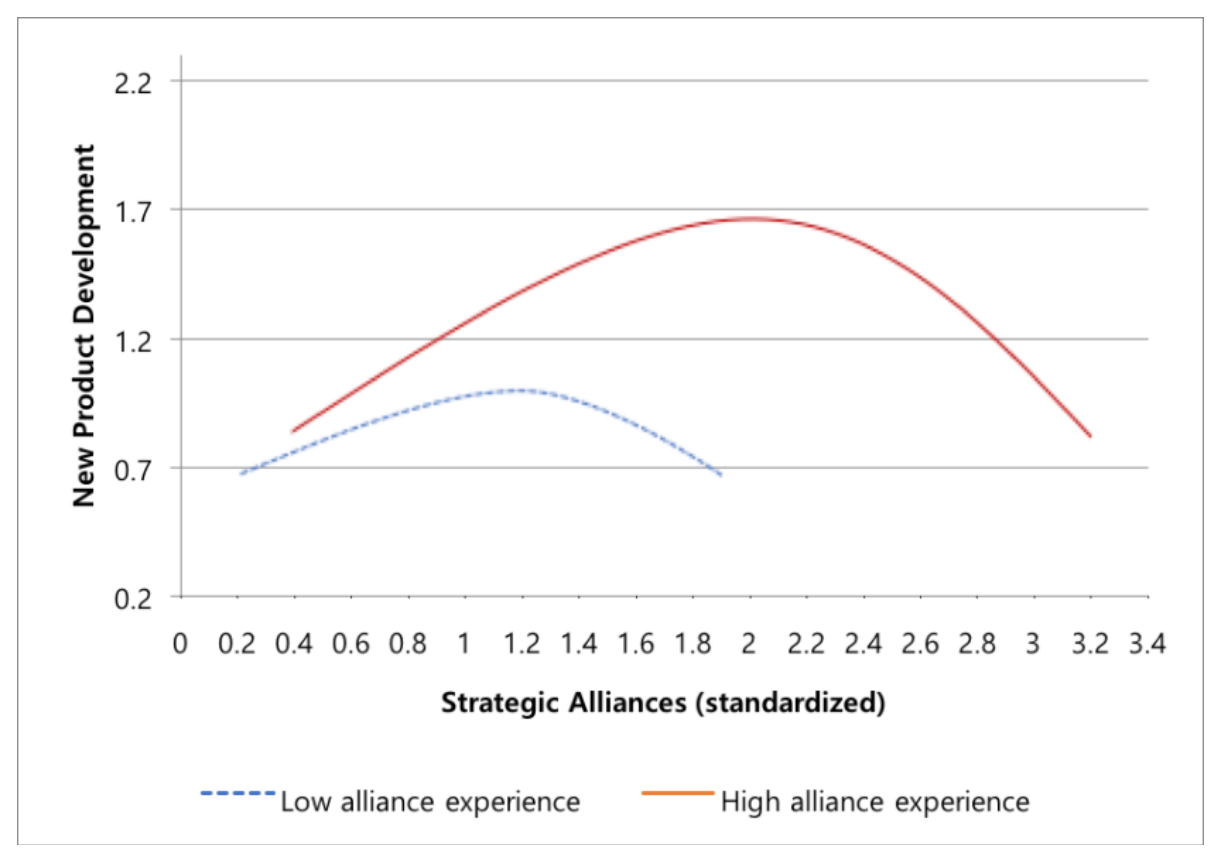


Table 3 examines the moderating effect of allying experience. Model 6 is the baseline model for ventures with lower alliance experience, whereas Model 8 is the baseline model for those with higher experience. Models 7 and 9 is fullspecification models respectively corresponding to Models 6 and 8, and each model shows a significant improvement over its base model. In both models, we uncovered that the relation between allying and innovation output is a reverse U-shape, seeing that the linear terms of alliance are positive whereas the squared terms of alliance are all negative and significant.

In Figure 2, we are able to test the moderating effect of allying experience through comparing each respective inflection point. By way of examining partial derivatives (Rothaermel \& Deeds, 2006) regarding allies in Models 7 and 9, we notice that the point of inflexion for ventures with lower alliance experience is 1.01 , whereas it is 2.15 for those with higher allying experience. These results indicate that allying experience have a positive moderating effect on the relation between alliance and NPD, thus providing support for Hypothesis 3 . Figure 2 illustrates and confirms this relationship.

Table 4. Results of GLM Poisson regression predicting NPD for subgroups of low level - and high level - of allying period

\begin{tabular}{|c|c|c|c|c|}
\hline 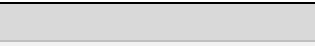 & \multicolumn{2}{|c|}{ Short allying period } & \multicolumn{2}{|c|}{ Long allying period } \\
\hline & Model 10 & Model 11 & Model 12 & Model 13 \\
\hline Intercept & $\begin{array}{l}1.42^{* * *} \\
(.04)\end{array}$ & $\begin{array}{l}1.29^{* * *} \\
(.04)\end{array}$ & $\begin{array}{l}2.08^{* * *} \\
(.05)\end{array}$ & $\begin{array}{l}2.01^{* * *} \\
(.05)\end{array}$ \\
\hline Firm size & $\begin{array}{l}0.15^{* *} \\
(.03)\end{array}$ & $\begin{array}{l}0.08^{* *} \\
(.03)\end{array}$ & $\begin{array}{l}0.09^{*} \\
(.05)\end{array}$ & $\begin{array}{l}0.02 \\
(.04)\end{array}$ \\
\hline Firm age & $\begin{array}{c}0.05^{*} \\
(.04)\end{array}$ & $\begin{array}{c}0.05^{*} \\
(.04)\end{array}$ & $\begin{array}{l}0.08^{* *} \\
(.04)\end{array}$ & $\begin{array}{c}0.07^{*} \\
(.05)\end{array}$ \\
\hline Firm innovativeness & $\begin{array}{l}0.03 \\
(.02)\end{array}$ & $\begin{array}{l}0.02 \\
(.02)\end{array}$ & $\begin{array}{l}0.02 \\
(.04)\end{array}$ & $\begin{array}{l}0.08^{*} \\
(.07)\end{array}$ \\
\hline Total alliance & & $\begin{array}{l}0.11^{* *} \\
(.06)\end{array}$ & & $\begin{array}{l}0.41^{* *} \\
(.08)\end{array}$ \\
\hline (Total alliance) 2 & & $\begin{array}{c}-0.07^{* *} \\
(.02)\end{array}$ & & $\begin{array}{c}-0.05^{* *} \\
(.03)\end{array}$ \\
\hline Log likelihood & -157.91 & -140.21 & -161.45 & -158.34 \\
\hline Chi-square & $48.98^{* * *}$ & $72.45^{* * *}$ & $68.24^{* * *}$ & $89.95^{* * *}$ \\
\hline Improvement over base & & $23.47^{* * *}$ & & $21.71^{* * *}$ \\
\hline
\end{tabular}

${ }^{*} \mathrm{p}<0.05 .{ }^{* *} \mathrm{p}<0.01 .{ }^{* * *} \mathrm{p}<0.001$

Figure. 3. Illustration of the moderating effect of alliance period on the relation between alliance and NPD

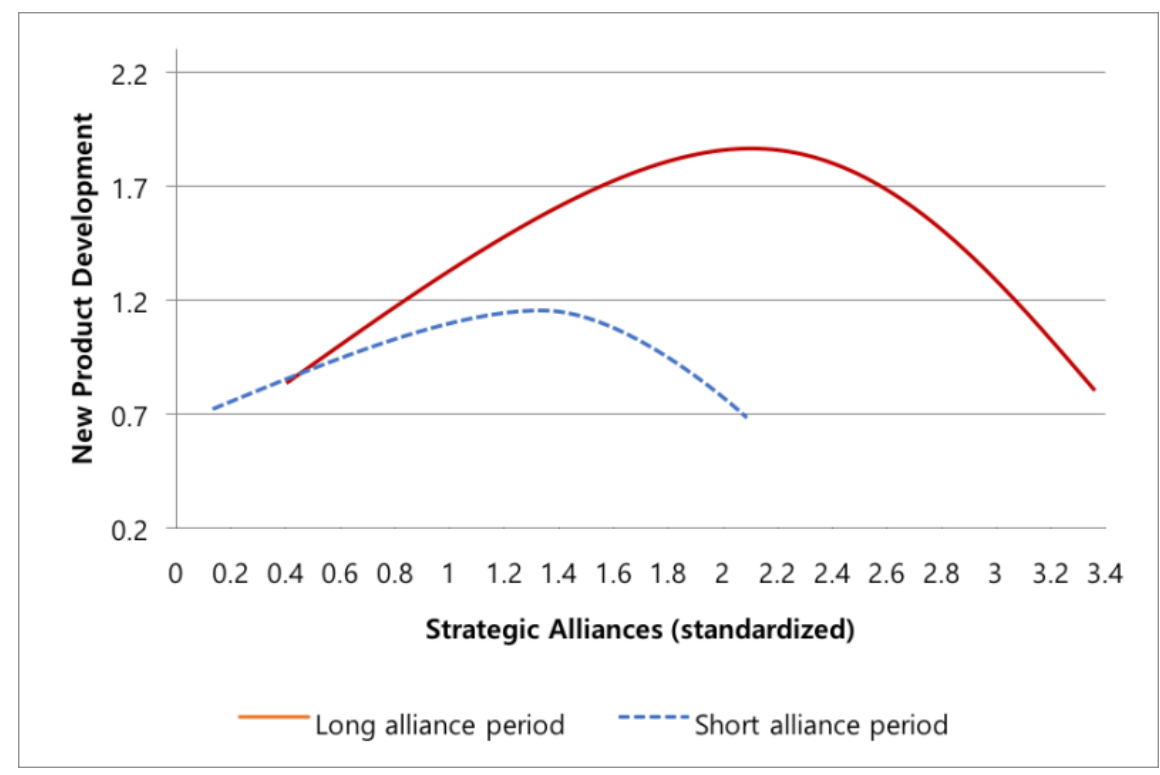


Table 4 and Figure 3 examine the moderating effect of alliance period. Model 10 is the baseline model for ventures with short alliance history, while Model 12 is the base model for those with longer alliance history. Models 11 and 13 is full-specification models respectively corresponding to Models 10 and 12 , and each model represents a significant improve over its corresponding baseline model. Following the same methodological procedure utilized to test Hypothesis 3, we are able to examine the moderating impact of average duration of alliances on the alliance innovation relation by comparing the respective inflection points.

Through examining partial derivatives (Rothaermel \& Deeds, 2006) regarding allies in Models 11 and 13, we notice that the inflexion point for firms with shorter alliance period is 1.31 , whereas it is 2.24 for those with longer allying period. These results indicate that a venture's average duration of allying positively moderates the relation between alliance and NPD, thus supporting for Hypothesis 4. Figure 3 illustrates and confirms this relationship.

\section{DISCUSSION}

This study focused on the role of organizational capacity for managing alliances in exploiting potential benefits from alliance networks. Although a number of studies have stressed the notion of alliance management capacity as a source of superior performance (Dyer \& Singh, 1998; Ireland, Hitt \& Vaidyanath, 2002; Schilke \& Goerzen, 2010; Schreiner, Kale, \& Corsten, 2009; Vandale \& Zaheer, 2014), few studies have empirically explored this capability, mainly because of various methodological constraints. In this regard, the present study provides some preliminary empirical evidence by uncovering the influence of allying experience and allying duration in a Korean venture context.

Because one of well-known obstacles in strategy research is about the inherently unobservable nature of a firm's capabilities, we tried to grasp observable consequences of a capability (Rothaereml \& Deeds, 2006). To deal with the issue, we developed and tested a research model which attempts to delineate some understanding of the effects of allying experience, period, and type on a high technology venture's capacity for managing multiple alliances. Especially, this study identified the point of decreasing gains in the relation between alliance and its innovation outputs. The results, which derived from a sample of 225 alliances in Korean photovoltaic industry, support all of the hypotheses.

This study makes some contributions to the alliance research. In beginning, the results showed that the relation between alliance and its innovation outcome is a reverse-U shaped, and this finding held true regardless of the alliance type. The results support the notion that a high level of alliance activity yields diminishing returns, and this relationship holds for all types of alliances.

Second, the results provide support for a valid proxy measure of a firm's capacity for managing alliances, namely its alliance history. In a theory of the alliance management capability, the notion that a firm's capacity for managing its differential allies is cultivated via continuous involvements in varying alliances over time is at the very center of it. Although previous studies have generally employed the raw count of alliances as a surrogate for alliance experience, we employed a more elaborate measure (i.e., the average duration of alliances), which is more tightly connected with the idea of experience accumulation (Rothaermel \& Deeds, 2006). Controlling for firm size, age, and innovativeness, we found that entrepreneurial ventures with more alliance experience could handle their allies more effectively. Indeed, there was no significant correlation among firm age and alliance experience. This result implies that the capacity for managing multiple alliances results from direct engagement in alliances, not simply from age. This finding further stresses the importance of alliance management capacity especially in the high-tech venture context. Taken together, the results imply that the capacity for managing diverse allies can be an important strategic weapon in volatile environments.

Finally, the results have another important implication for research on firms' capabilities. Our methodological approach provides support for the contention that large-scale, quantitative studies designed for testing capabilityrelated themes should attempt to grasp discernible objects of firm competence, rather than trying to gauge competence itself. 


\section{LIMITATIONS AND FUTURE RESEARCH}

Despite some theoretical and methodological contributions, our study has several limitations. First, there is a critical issue with regard to the definition and measurement of capacity for managing alliance. We relied on an indirect measure of the capacity, following the approach which Rothaermel and Deeds (2006) proposed. Specifically, we tracked entrepreneurial venture's alliance management capability and its observable results, which is the number of allies that a firm could handle effectively. Further, this study's measure of alliance management is far from complete. Although the capability for alliance management is surely a multidimensional construct, we grasped only one aspect of this capability. Other facets encompass the capacity to choose suitable partners, set up mutually beneficial relationships, transfer best practices, and interchange and create new knowledge. Future studies should reflect various dimensions of the capacity and focus on developing and validating the measures of alliance management capability.

Second, although the results provide some tentative evidence of a positive relation between a firm's capacity for managing multiple allies and its performance, future studies are needed to consider other performance dimensions especially suitable for entrepreneurial ventures.

Third, given the cross-sectional nature of our study, we determined the different points of inflexion at one point in time. However, organizational capabilities develop, evolve, and change over time. In this regard, future research should elucidate the evolution of a firm's capacity for managing alliances over time so as to advance our understanding of the dynamics of allying capabilities.

As a final note, future research could also address the issue of how economic rents from alliance are created and distributed. We believe that the concept of alliance management capability plays a major role in addressing this important question.

\section{AUTHOR BIOGRAPHIES}

Sang-Mi Moon (Ph.D. Kyungpook National University) is a manager at Korea Institute for Robot Industry Advancement (KIRIA), Daegu, Republic of Korea. She earned her Ph.D. in strategy and organization from the School of Business Administration, Kyungpook National University, Korea. Her research interests include external knowledge, firm innovation, strategic change, strategic alliance and innovation strategy. E-mail: smmoon@kiria.org (First author)

Moon-Goo Huh (Ph.D. Korea University) is a professor of strategy and organization at the School of Business Administration, Kyungpook National University, Republic of Korea. His current research interests include firm innovation, exploration and exploitation, modes of ambidexterity, strategic and organizational change, knowledge creation, and social capital. He has authored and coauthored seven books, and published over 50 research articles in peer-reviewed journals. He served as a president of the Korean Society of Strategic Management. E-mail: moongoo@knu.ac.kr (Corresponding author)

\section{REFERENCES}

Anand, B., \& Khanna, T. (2000). Do firms learn to create value? The case of alliances. Strategic Management Journal, 21, 295315.

Argote, L. (2012). Organizational learning: Creating, retaining and transferring knowledge. Springer Science \& Business Media.

Bamford, J. D., \& Ernst, D. (2002). Managing an alliance portfolio. The McKinsey Quarterly, 3, 29-39.

Barney, J.B. (1991). Firm resources and sustained competitive advantage. Journal of Management, 11, 791-800.

Deeds, D.L., \& Hill, C.W.L. (1996). Strategic alliances and the rate of new product development: an empirical study of entrepreneurial biotechnology firms. Journal of Business Venturing, 11, 41- 55.

Duysters, G., Heimeriks, K. H., Lokshin, B., Meijer, E., \& Sabidussi, A. (2012). Do firms learn to manage alliance portfolio diversity? The diversity-performance relationship and the moderating effects of experience and capability. European Management Review, 9(3), 139-152.

Dyer, J.H., \& Singh, H. (1998). The relational view: cooperative strategy and sources of interorganizational competitive 
advantage. Academy of Management Review, 23, 660-679.

George, G., Zahra, S. A., Wheatley, K. K., \& Khan, R. (2001). The effects of alliance portfolio characteristics and absorptive capacity on performance: A study of biotechnology firms. Journal of High Technology Management Research, 12, 205-226.

Godfrey, P.C., \& Hill, C.W.L. (1995). The problem of unobservables in strategic management research. Strategic Management Journal, 16, 519-533.

Golden, B., \& Zajac, E. (2001). When will boards influence strategy? inclination $\times$ power $=$ strategic change. Strategic Management Journal, 22, 1087-1111.

Gulati, R., (1998). Alliances and networks. Strategic Management Journal, 19, 293-317.

Harbison, J. R., \& Pekar, P. (1998). Smart alliances: A practical guide to repeatable success. San Francisco: Booz, Allen \& Hamilton.

Heimeriks, K. H., \& Duysters, G. (2007). Alliance capability as a mediator between experience and alliance performance: An empirical investigation into the alliance capability development process. Journal of Management Studies, 44, 25-49.

Hoang, H., \& Rothaermel, F. T. (2005). The effect of general and partner-specific alliance experience on joint R\&D project performance. Academy of Management Journal, 48, 332-345.

Ireland, R.D., Hitt, M.A., \& Vaidyanath, D. (2002). Alliance management as a source of competitive advantage. Journal of Management, 28, 413- 446.

Jiang, R. J., Tao, Q. T., \& Santoro, M. D. (2010). Alliance portfolio diversity and firm performance. Strategic Management Journal, 31, 1136-1144.

Kale, P. \& Singh, H. (1999). Alliance Capability and Success: A Knowledge-Based Approach. Working Paper, Wharton School, University of Pennsylvania, Philadelphia, $P A$.

Kelley, D.J., \& Rice, M.P. (2002). Advantage beyond founding. Strategic use of technologies. Journal of Business Venturing, 17, 41-57.

Koka, B. R., \& Prescott, J. E. (2008). Designing alliance networks: The influence of network position, environmental change, and strategy on firm performance. Strategic Management Journal, 29, 639-661.

Koza, M., \& Lewin, A. (2000). Managing partnerships and strategic alliances: Raising the odds of success. European Management Journal, 18, 146-151.

Krishnan, R., Martin, X., \& Noorderhaven, N. G. (2006). When does trust matter to alliance performance?. Academy of Management journal, 49(5), 894-917.

Lavie, D. (2007). Alliance portfolios and firm performance: A study of value creation and appropriation in the U.S. software industry. Strategic Management Journal, 28, 1187-1212.

Lavie, D., \& Miller, S. R. (2008). Alliance portfolio internationalization and firm performance. Organization Science, 19, 623646.

Lavie, D., Haunschild, P. R., \& Khanna, P. (2012). Organizational differences, relational mechanisms, and alliance performance. Strategic Management Journal, 33(13), 1453-1479.

Leiblein, M.J., Reuer, J.J. (2004). Building a foreign sales base: the roles of capabilities and alliances for entrepreneurial firms. Journal of Business Venturing, 19, 285-307.

Oliva, R., \& Sterman, J. D. (2001). Cutting corners and working overtime: Quality erosion in the service industry. Management Science, 47(7), 894-914.

Parise, S., \& Casher, A. (2003). Alliance portfolios: Designing and managing your network of business-partner relationships. Academy of Management Executive, 17(4), 25-39.

Park, S. H., \& Ungson, G. R. (2001). Interfirm rivalry and managerial complexity: A conceptual framework of alliance failure. Organization Science, 12(1), 37-53.

Reuer, J. J. \& Ragozzino, R. (2006). Agency hazards and alliance portfolios. Strategic Management Journal, 27, $27-44$.

Rothaermel, F. T., \& Deeds, D. L. (2006). Alliance type, alliance experience and alliance management capability in hightechnology ventures. Journal of Business Venturing, 21, 429-460.

Rothaermel, F.T., (2001). Incumbent's advantage through exploiting complementary assets via interfirm cooperation. Strategic Management Journal, 22, 687- 699.

Sampson, R. C. (2007). R\&D alliances and firm performance: The impact of technological diversity and alliance organization on innovation. Academy of Management Journal, 50(2), 364-386.

Sampson, R., (2002). Experience, learning and collaborative returns in R\&D alliances. Working Paper. New York University.

Schilke, O., \& Goerzen, A. (2010). Alliance management capability: An investigation of the construct and its measurement. Journal of Management, 36, 1192-1219.

Schreiner, M., Kale, P., \& Corsten, D. (2009). What really is alliance management capability and how does it impact alliance outcomes and success? Strategic Management Journal, 30, 1395-1419.

Stuart, T.E., Hoang, H., \& Hybels, R.C. (1999). Interorganizational endorsements and the performance of entrepreneurial ventures. Administrative Science Quarterly, 44, 315- 349.

Tsang, E. W. K. (2002). Acquiring knowledge by foreign partners from international joint ventures in a transition economy: learning-by-doing and learning myopia. Strategic Management Journal, 23, 835-854.

Vandale, R., \& Zaheer, A. (2014). Surviving bear hugs: Firm capability, large partner alliances, and growth. Strategic 
Management Journal, 35, 566-577

Wassmer, U. (2010). Alliance portfolio: A review and research agenda. Journal of Management, 36, 141-171.

Wuyts, S., \& Dutta, S. (2014). Benefiting from alliance portfolio diversity: The role of past internal knowledge creation strategy. Journal of Management, 40(6), 1653-1674.

Zollo, M., Reuer, J. J., \& Singh, H. (2002). Interorganizational routines and performance in strategic alliances. Organization science, 13(6), 701-713. 